\title{
Towards an integrated model of socioeconomic biodiversity drivers, pressures and impacts. A feasibility study based on three European long-term socio-ecological research platforms
}

\author{
Helmut Haberl ${ }^{\mathrm{a},} \square$, Veronika Gaube ${ }^{\mathrm{a}}$, Ricardo Díaz-Delgado ${ }^{\mathrm{b}}$, Kinga Krauze ${ }^{\mathrm{c}}$, \\ Angelika Neuner ${ }^{\mathrm{d}}$, Johannes Peterseil ${ }^{\mathrm{d}}$, Christoph Plutzar ${ }^{\mathrm{e}}$, \\ Simron J. Singh ${ }^{a}$, Angheluta Vadineanu ${ }^{\mathrm{f}}$ \\ ${ }^{a}$ Institute of Social Ecology, Faculty for Interdisciplinary Studies, Klagenfurt University, Schottenfeldgasse 29, 1070 Vienna, Austria

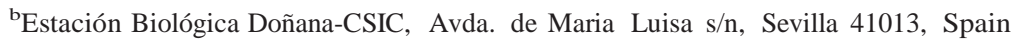 \\ 'International Centre for Ecology, PAS, 3 Tylna Street 90-364 Lodz, Poland \\ ${ }^{\mathrm{d}}$ Federal Environment Agency Austria, Spittelauer Lände 5, 1090 Vienna, Austria \\ eVINCA-Vienna Institute for Nature Conservation and Analyses, Gießergasse 6/7, 1090 Vienna, Austria \\ ${ }^{\mathrm{f}}$ Department of Systems Ecology and Sustainability (DSES), University of Bucharest, Spl. Independentei 91-95, Sector 5, Bucharest, Romania
}

Keywords:

Biodiversity

Long-term socio-ecological research (LTSER)

Socioeconomic drivers

Pressures on biodiversity

Human appropriation of net primary

production (HANPP)

Socioeconomic metabolism

\section{A B S T R A C T}

Effective policies to slow the rate of anthropogenic biodiversity loss should reduce socioeconomic pressures on biodiversity, either directly or by modifying their underlying socioeconomic driving forces. The design of such policies is currently hampered by the limited understanding of socioeconomic drivers of and pressures on biodiversity as well as by lacking data, indicators and models. In order to improve understanding of these issues we here propose a conceptual model of socioeconomic biodiversity drivers and pressures. The model is based on the drivers-pressures-impacts-states-responses (DPSIR) scheme and on the socioeconomic metabolism approach. The aim of the model is to guide research aimed at improving our understanding of socioeconomic biodiversity pressures and drivers and to serve as a basis for the development of formal, quantitative models in that field. Based on three European long-term socio-ecological research (LTSER) platforms, we analyze the model's applicability and suitability as well as data availability and research needs. These platforms are the Danube Delta Wetland System in Romania, the Doñana in Spain and the Eisenwurzen in Austria. An empirical analysis of the relationship between the human appropriation of net primary production (HANPP) and breeding bird richness in the Eisenwurzen demonstrates the ability of HANPP to provide a link between socioeconomic pressures/drivers and biodiversity. The analysis of the case studies underlines the potential utility of the conceptual model to guide future research into socioeconomic biodiversity drivers and pressures. However, considerable investments in monitoring and reconstruction of past trajectories as well as in model development will be required before mathematical (computer) models of the interrelation processes between society and ecosystems can be successfully deployed. 
$\square$ Corresponding author. Fax: +43 15224000477 .

E-mail address: helmut.haberl@uni-klu.ac.at (H. Haberl).

URL: http://www.uni-klu.ac.at/socec (H. Haberl).

\section{Introduction}

The conservation of biodiversity is an important goal in a sustainability context. Presently, the world experiences biodiversity loss at a yearly rate that exceeds the natural rate of species loss by a factor of perhaps 100 or even 1000 (Chapin et al., 2000). In 2002, the World Summit on Sustainable Development and the Convention of Biodiversity adopted the target to significantly reduce the rate of biodiversity loss by the year 2010 (CBD, 2003). In its 6th environmental action programme, the European Union in 2002 formulated the goal to halt the loss of biodiversity until 2010 (EEA, 2007). Such policies generally recognize three main levels of biodiversity: (a) genetic diversity, (b) species diversity and (c) ecosystemlevel diversity, i.e. the diversity of habitats and landscapes. The notion of species diversity is in itself multi-faceted and includes measures of species richness (i.e. the number of species present in a defined area) and abundance (i.e. the size of populations, both in absolute numbers and the relative abundances of different species). Monitoring and reporting the state of biodiversity, including its spatial patterns and its change through time, is therefore not straightforward (Biggs et al., 2007; Delbaere, 2002; Heywood and Watson, 1995; Magurran, 1988; Scholes and Biggs, 2005). A large proportion of current biodiversity research is based on bio-ecological methods to analyse patterns and trends of biodiversity. Results achieved using these various approaches to measure and interpret biodiversity have triggered widespread concerns among scientists and even the general public over its rapid loss.

There is a growing recognition that effective policies for biodiversity conservation need to focus on the reduction of socioeconomic pressures on biodiversity, either directly or through modification of their underlying driving forces (Haberl et al., 2007b; Spangenberg, 2007). Mitigation of pressures on biodiversity through modification of their underlying socioeconomic drivers is thought to be the most effective and durable option to reduce the rate of biodiversity loss. Such measures need to be underpinned by broad research approaches that integrate social sciences and economics with biodiversity research. Unfortunately, the understanding of the link between (socioeconomic) drivers of biodiversity and subsequent pressures is even more scattered and incomplete than that of biodiversity patterns and change. Reliable, wellvalidated indicators and models are almost absent in that field (e.g., Delbaere, 2003; Haberl et al., 2007b), as the biodiversity research community has only recently begun to implement schemes such as the drivers-pressures-states-impactsresponses (DPSIR) approach (e.g., EEA, 2005, 2007; see Fig. 1).

This paper is an attempt to close this gap between drivers and pressures related to biodiversity by presenting a conceptual model (Section 2) based on DPSIR and the socioeconomic metabolism approach (Ayres and Simonis, 1994; FischerKowalski, 1998; Fischer-Kowalski and Hüttler, 1998; MartinezAlier, 1999; Weisz et al., 2006). The utility of the conceptual model is then tested using data and information from three European long-term socio-ecological research (LTSER) platforms (see Fig. 2). These research platforms were established within the LTER Europe network (www.lter-europe.net) and the framework of A Long Term Ecological Research Network (ALTER-Net). ALTER-Net is a network-of-excellence project within the 6th framework programme of the European Commission. LTSER platforms were designed as a research infrastructure to support integrated socioeconomic and ecological research and monitoring of the long-term development of society-nature interaction within the context of global environmental change (Haberl et al., 2006b). LTSER platforms usually comprise hundreds to thousands of square kilometres, a sizeable population and considerable gradient of land-use intensity. In Europe, around 11 LTSER platforms have been established to investigate and foresee the

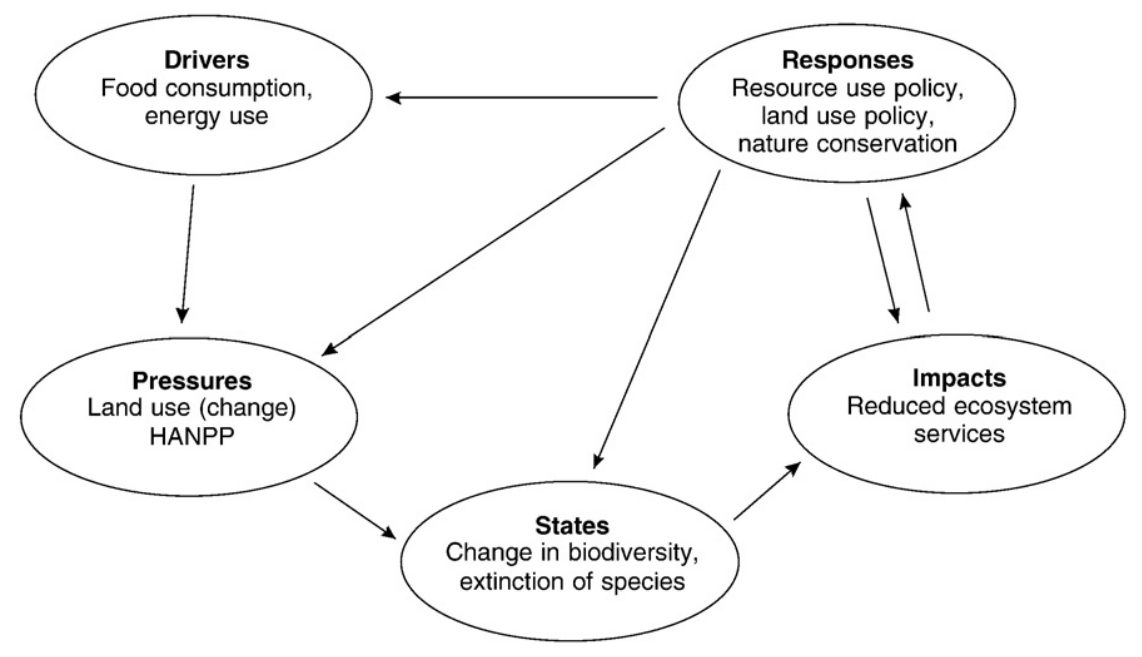

Fig. 1 - The drivers-pressures-states-impacts-responses (DPSIR) framework applied to biodiversity. For example, consumption of food, bio-energy or other kinds of biomass implies that natural ecosystems are replaced with agro-ecosystems (land use), resulting, among others, in a reduction of biomass availability in ecosystems (HANPP) and other pressures on biodiversity. Land 
use therefore results in a changed state, i.e. a change in biodiversity and maybe the extinction of species. This in turn may affect ecosystem services, i.e. result in an impact on society. Society responds with a variety of policies aimed at changing patterns of resource consumption, land use or nature conservation. Sources: Modified after EEA (2005) and EEA (2007). 


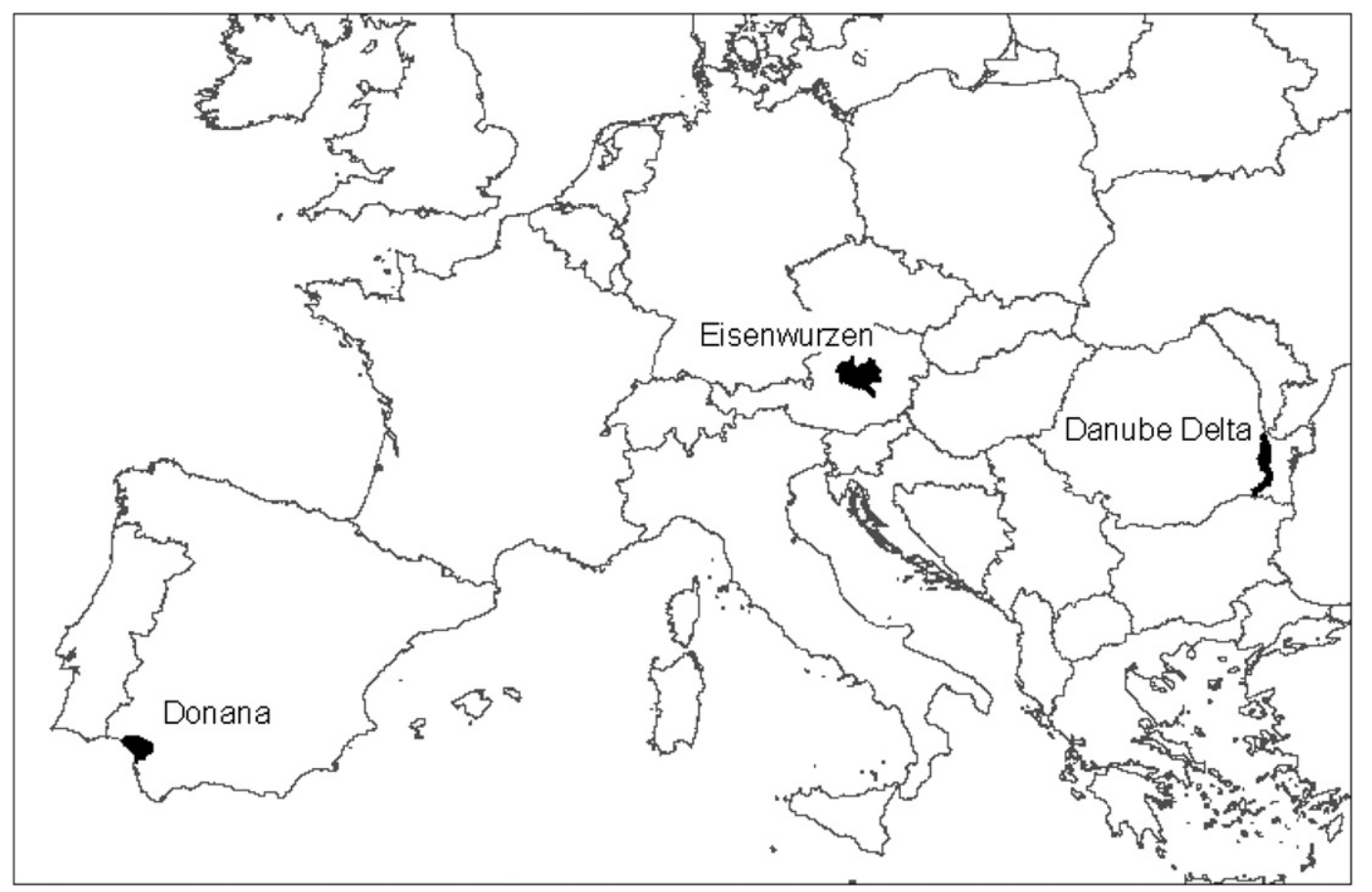

Fig. 2 -Location and limits of the three LTSER platforms Donana (Spain), Eisenwurzen (Austria) and Inner Danube Delta (Romania).

evolution of that interaction according to a defined set of ecological and socioeconomic themes (Ohl et al., 2007). Three LTSER platforms, the Danube Delta Wetland System in Romania (Section 3), the Doñana in Spain (Section 4), and the Eisenwurzen in Austria (Section 5) allow for a feasibility check of the model with respect to appropriateness of the general model structure, data availability and research needs. Section 6 presents an empirical analysis of the interrelation between land-use intensity, measured as HANPP, the "human appropriation of net primary production" (Haberl et al., 2007a), and avifauna diversity in the Eisenwurzen. Section 7 discusses and concludes the preceding material.

\section{A conceptual model of socioeconomic biodiversity drivers and pressures}

Our model is intended to serve as a conceptual framework for analyzing the links between socioeconomic activities and biodiversity change. It seeks to help closing gaps in our understanding of interrelations between drivers, pressures and impacts in the DPSIR scheme. It also seeks to support the development of algorithmic (mathematical) models of these interrelations and structure monitoring, research and databases in order to improve our understanding of socioeconomic drivers of biodiversity change.

It is almost impossible (and probably not too useful) to try and establish a comprehensive list of human activities that affect biodiversity. It would be almost endless. Instead, we here present a scheme of main categories of biodiversity pressures based on a review of the relevant literature (e.g., Biggs et al., 2007; Chapin et al., 2001; Delbaere, 2002; EEA, 2007;
Haberl et al., 2007b; Heywood and Watson, 1995; Sala et al., 2000; Spangenberg, 2007; Scholes and Biggs, 2005) and discuss their relations to the MEFA framework (Table 1). This overview underlines the point made recently by Spangenberg (2007, pp.151ff) that all major pressures on biodiversity are more or less directly linked to human use of resources such as

Table 1 - The interrelations between main pressures on biodiversity and resource flows as assessed in the MEFA (material and energy flow accounting) framework
Main categories of pressures on biodiversity

Direct impacts of exploitation (e.g., hunting or poaching of rare/endangered animals, collection of rare/endangered plants)

Habitat loss and fragmentation Land demand, HANPP due to land use (change) Intentional and unintentional release of chemicals (fertilizers, pesticides, pollutants)

Introduction of alien species

Climate change
Parameters/flows accounted for in the MEFA framework

Domestic extraction of biomass $\mathrm{NPP}_{\mathbf{h}} \ldots$... an important component of HANPP
Outflows from socioeconomic metabolism (part of the "Domestic Processes Output", DPO, as accounted for in Material Flow Analysis MFA)

Related to trade flows as accounted for in MFA (e.g., import/export of living animals and biomass) Results to a large extent from fossil fuel combustion (accounted for in MFA and Energy Flow Analysis, EFA)
Sources: see text 
materials, energy or land. We conclude that a modification of unsustainable socioeconomic trajectories would not only result in a reduction of biodiversity pressures, but could also help to meet other environmental and sustainability objectives. This phenomenon has been denoted as "mainstreaming biodiversity protection" in other policy fields (Spangenberg, 2007).

Table 1 also demonstrates that scaling issues are extremely important when trying to understand socioeconomic biodiversity pressures and drivers on a regional level. According to their purpose, LTSER platforms are large enough to comprise a sizeable human population as well as significant gradients in patterns and intensity of human use of ecosystems, i.e. they are defined at a regional (landscape) scale (Haberl et al., 2006b; Hasenauer et al., 2007; Mirtl and Krauze, 2007). They are too large to apply an "integrated monitoring" approach based on measurements and observation (Zechmeister et al., 2007). A combination of modelling methods based on GIS, remote sensing, statistical and survey data as well as measurement and observation data is therefore required. At the same time, LTSER platforms are small enough for environmental effects of their population beyond their boundary usually being very important. For example, a considerable percentage of the food eaten by humans within a defined area sized 100-10,000 km² anywhere in Europe will usually stem from agricultural activities outside that area. The production of that food therefore mostly affects biodiversity and ecosystems elsewhere. The reverse is often true as well, as a region of that size may also be a significant exporter. This makes it all but straightforward to decide to which socioeconomic system the ecological effects associated with food production should be attributed.

At the same time, impacts on the ecosystems within a region that primarily or even exclusively result from socioeconomic systems beyond its boundary may be very important or even dominant (Fischer-Kowalski and Erb,
2003). For example, the inflow of pollutants, airborne or through water flows (e.g., in rivers), may be highly important (see case studies). Climate change affecting biodiversity on a regional scale is also almost independent of greenhouse gas emissions within a region of that size because these emissions are usually negligible compared to global emission totals. On the other hand, greenhouse gas emissions within a region may significantly contribute to that region's aggregate pressure on biodiversity if biodiversity pressures on a global scale are also taken into account. Shifts between local and global pressures (e.g., translocation of production processes beyond a region's boundary) must also be considered (Weisz, 2006).

Another important point is that boundaries of LTSER platforms seldom coincide with administrative boundaries. On the one hand this means that the conceptual model presented here can easily be applied to regions of a similar size that coincide with one or several administrative units, at least as far as socioeconomic data are concerned. On the other hand this implies that socioeconomic trajectories within the region under consideration may not only depend on conditions of political or economic framework on higher levels (e.g., the province, the nation state or even supranational entities such as the European Union), they may even be influenced by different provinces or other administrative units if the region cuts across their respective territories.

These considerations were taken into account in forging the conceptual model displayed in Fig. 3. It shows that the main local socioeconomic drivers such as the human population, households, economic activities, technology and local policy are influenced by socioeconomic drivers on other levels. Their behaviour might also reflect attempts to improve the condition of ecosystems or biodiversity on a local level ("responses"). These drivers result in pressures that affect the local environment ("local socioeconomic pressures"). At the same time, these pressures may directly (through

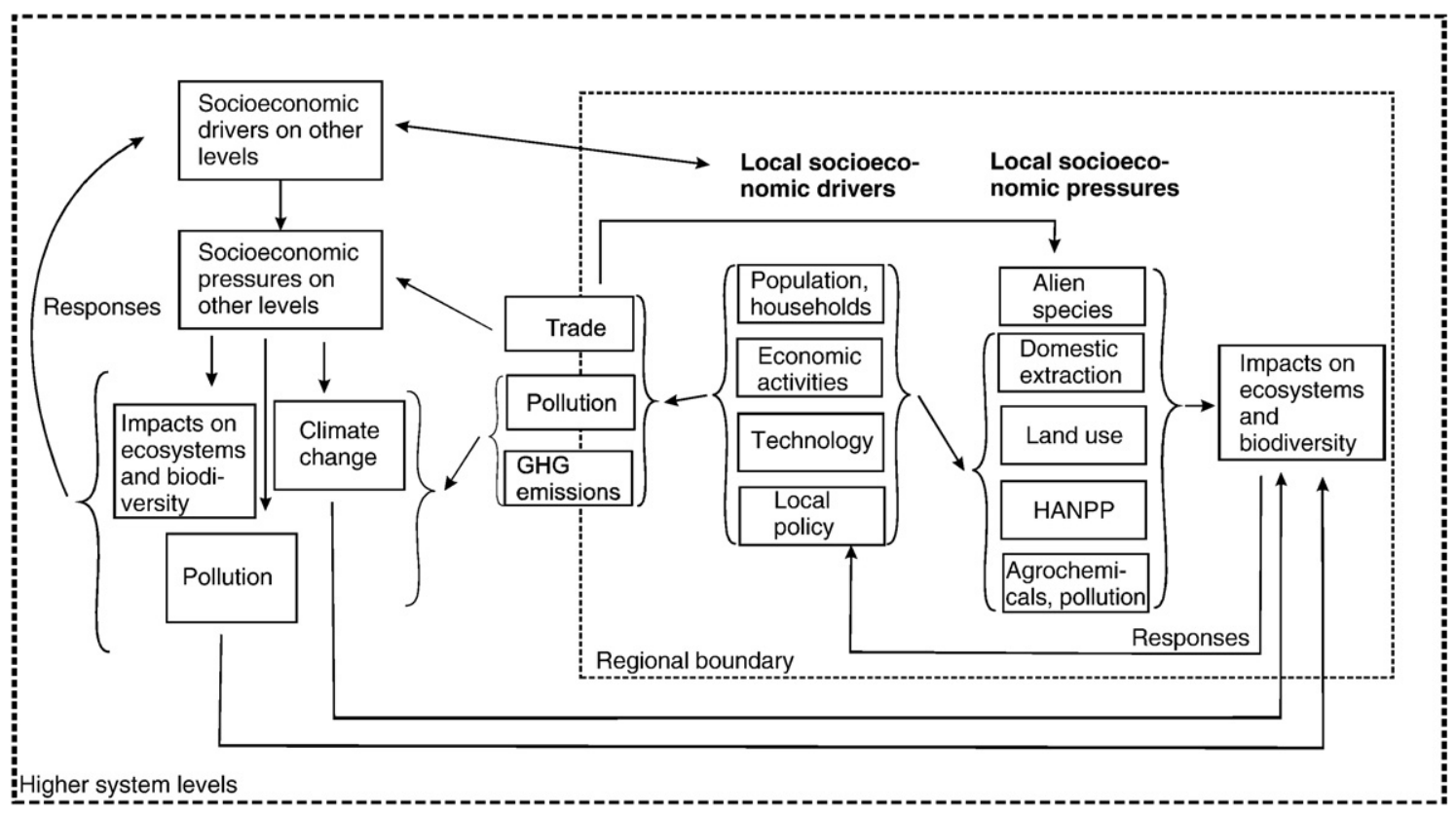

Fig. 3 -Socioeconomic biodiversity pressures and drivers - a conceptual model. 

pollution and greenhouse gas emissions) as well as indirectly (through trade) contribute to pressures on ecosystems and biodiversity outside the region's boundary. Local ecosystems and biodiversity are also affected by inflowing pollution as well as impacts of climate change.

The use of the socioeconomic metabolism approach, an established conceptual framework of society-nature interaction, was useful to articulate the main categories of pressures on biodiversity with potential parameters and indicators (Ayres and Simonis, 1994; Fischer-Kowalski, 1998; Fischer-Kowalski and Hüttler, 1998; Haberl et al., 2006b; Martinez-Alier, 1999; Weisz et al., 2006; see Table 1). The socioeconomic metabolism approach is based on the notion that society-nature interaction is a process in which a symbolic, cultural sphere (a system of recursive communication that may be denoted as "culture") interacts with the biophysical sphere; that is, a system of physical objects that interact through flows of energy, substances or materials (Fischer-Kowalski and Weisz, 1999).

For example, a change in the price of crude oil (a potent communicative signal) is able to influence the quantities of different types of oil products used in a country and thus change its socioeconomic metabolism, i.e. the import or domestic extraction of crude oil, its distribution through pipelines or on ships, its transformation in refineries, its combustion and the resulting wastes and emissions. This interaction is complex: A notable oil price change shapes myriads of different decisions and communicative processes including media reports, dinner conversations and cost-benefit assessments. Thereby, it affects uncountable individual human actions, from the decision to cycle to work instead of using a car to investment decisions in favour of energy-saving technologies or even settlement or industrial development plans that ultimately affect a variety of resource flows and emissions. Many other socioeconomic drivers act much more subtly or are less well understood than oil price changes. For example, changes in family structures or working time regulations may also affect resource use patterns (Schor, 2005). Nevertheless, the concept to focus on interrelations between well-understood indicators used traditionally in the social sciences and in economics and biophysical stocks and flows associated with human activities has proven to be useful in guiding interdisciplinary studies of society-nature interactions that are relevant to sustainability (Clark and Dickson, 2003; Kates et al., 2001).

The metabolism approach has been seminal in generating tools to assess and monitor biophysical dimensions of socioeconomic change (Cleveland et al., 2001; Daniels and Moore, 2001; Daniels, 2002; Fischer-Kowalski, 1998; Fischer-Kowalski and Hüttler, 1998). The notion of a MEFA ("materials and energy flow analysis") framework was introduced as an attempt to systematize the accounts along the main dimensions of socioeconomic resource use: (1) materials, (2) energy and (3) land (Haberl et al., 2004a; Krausmann et al., 2004):

1. Material flow analysis (MFA) is an accounting system to trace socioeconomic flows of materials from domestic extraction and import to export and emissions. It can also be used to establish consistent time series of important MFA-derived indicators (Eurostat, 2001, Weisz et al., 2006).
2. Energy flow analysis (EFA) is an accounting method for socioeconomic energy flows. It is based on usual statistical data and conventional energy balances that are extended by additional accounts (above all of biomass) in order to be consistent with MFA and applicable in different societal contexts (Haberl, 2001a,b, 2006a).

3. The land area needed for a society's resource consumption may be accounted for by calculating its "actual land demand." This indicator is conceptually related to the ecological footprint (Wackernagel and Rees, 1996). Contrary to conventional ecological footprint accounts, the indicator "actual land demand" considers actually used hectares without application of weighting factors (Erb, 2004). The "human appropriation of net primary production" (HANPP) is useful to gauge the intensity with which that land is used (Haberl et al., 2001, 2007a). HANPP analyzes changes in the availability of trophic energy (biomass) in ecosystems resulting from land conversion and harvest. HANPP is a measure of socio-ecological material flows.

Additional accounts, including analyses of socioeconomic or socioecological carbon, nitrogen or phosphorous flows and indicators based on the ecological footprint approach can complement the MEFA framework.

The following sections analyze drivers, pressures and states of biodiversity in the three case studies, thus allowing for a feasibility check of the conceptual model. We provide useful insights into (i) the role and value of the inter- and transdisciplinarity research on socio-ecological systems; (ii) establishment and further development of integrated research platforms; (iii) critical analysis and synthesis of knowledge on biodiversity as affected by socioeconomic drivers; (iv) identification of the data and knowledge gaps and, (v) extending the research and monitoring agenda.

\section{Case study 1 - the Danube delta, Romania}

The Inland Danube Delta-Socio Ecological System is characterized by a network of branches of the Danube river. The region with a size of approximately $3200 \mathrm{~km}^{2}$ extends along a river stretch of $215 \mathrm{~km}$, between 150 and $365 \mathrm{~km}$ upstream from the Black Sea Coast and, between the Southern Romanian Plain, and the Dobrogean Plateau. The LTSER platform includes a particular type of local socio-ecological system that belongs to a hierarchy of socio-ecological systems located in the Danube River catchment (Fig. 2 and Figure S1, supporting online material). The case study builds upon research of the Department of Systems Ecology and Sustainability, University of Bucharest, that integrates a large bulk of ecological and biological data collected by different research teams from 1900 to 1970 as well as databases produced by long-term ecosystem research carried out after 1970 by a network of experts from a group of six universities and research institutes.

The reference configuration and functional regime of the Inland Danube Delta-Socio Ecological System goes back to the beginning of the 1950s, when the area was inhabited by $\sim 440,000$ humans. $53 \%$ of the total population lived in two medium 


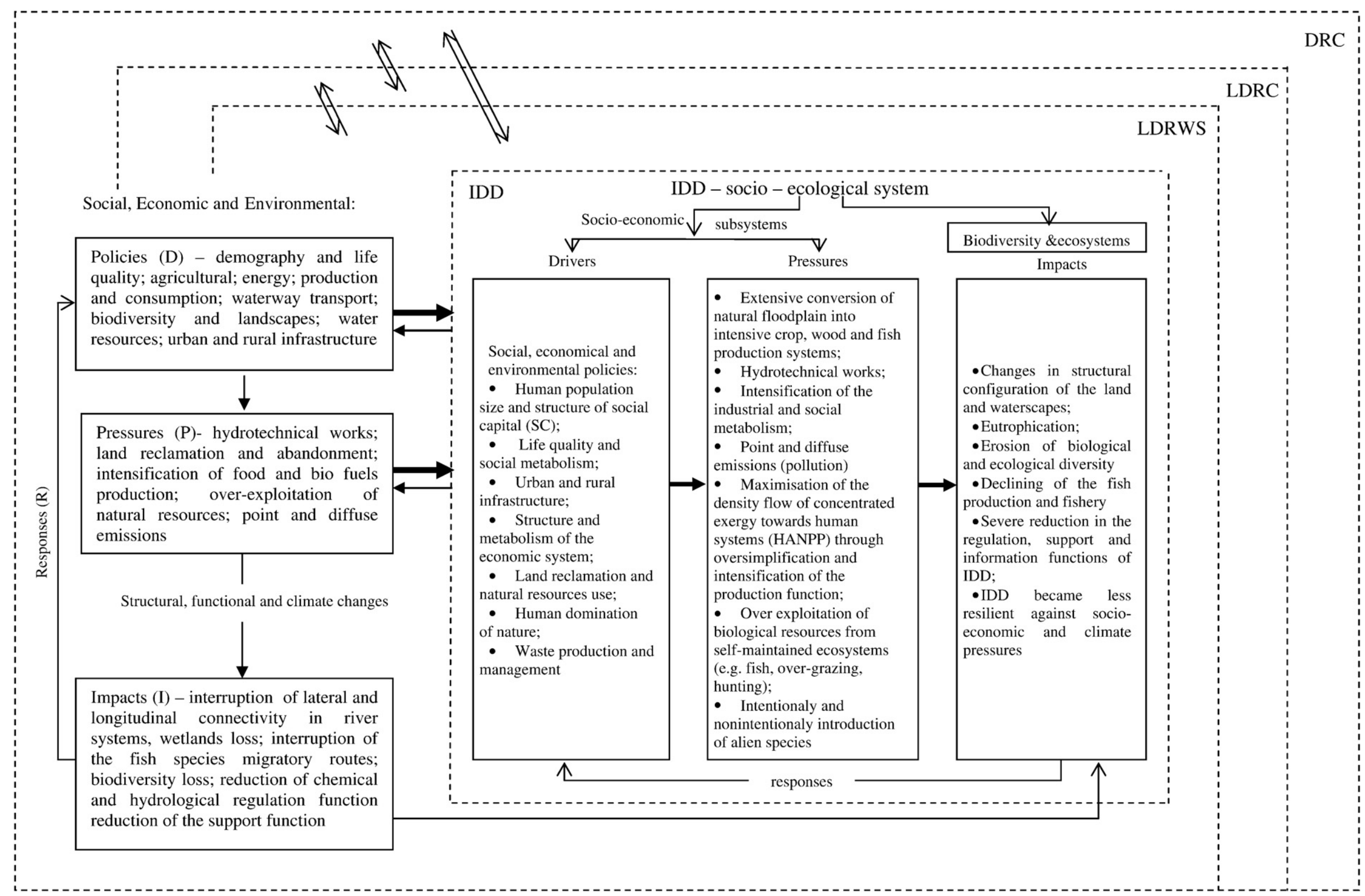

Fig. 4 - Social and economic drivers and pressures on biodiversity and ecosystems in the Inland Danube Delta(IDD) socio-ecological system (LTSER platform) and its relationships with that from higher hierarchical levels. - . . - . - - boundaries between hierarchical socio-ecological systems established at: DRC/Danube River catchment; LDRC/Lower Danube River Catchment; LDRWS/Lower Danube River Wetland System. The left side compartments contains the major types of drivers and pressures and major categories of effects, which differs qualitatively and quantitatively among the identified socio-ecological Systems. 
( 120,000 inhabitants) and one small (b20,000 inhabitants) cities, the remaining $47 \%$ of the population in over 70 villages. $65 \%$ of the economically active population were employed in primary economic sectors, mainly agriculture and fishery, 25\% in food processing and manufacturing sectors and $10 \%$ in tertiary sectors, in particular trade and waterway transport (Vadineanu, 2008). Before the campaign for agricultural land reclamation that started in the late 1950s, the inland delta contained a large number of shallow lakes, ponds and marshes, linked to each other by river arms or man-made channels. This network covered almost $40 \%$ of the total surface of the inland delta. Another $40 \%$ of the area used to be flooded for 3-7 months per year and the remaining $20 \%$ of the area for a couple of weeks per year (Antipa, 1910; Vadineanu et al., 2003).

These temporarily flooded areas provided a wide range of excellent habitats for spawning, breeding, nesting and feeding of a large number of fishes (N60 species) and birds (N150 species) as well as habitats for more than 1680 plant species and a total of 3800 animal species. The area included very productive wet grasslands and alluvial forests. The variation in the river's hydrologic pulse and the corresponding duration of floods allowed the local population to practice extensive and traditional crop production (e.g., corn and vegetables) and animal raising (mostly cattle, horses, sheep and pigs). Under natural and semi-natural conditions, the Inland Danube Delta ecosystems were able to provide annually to the local socioeconomic system significant and diverse biological resources such as 8-10 kilotons per year (kt/yr) of fish yield (1 kt =1,000 tons $=10^{3} \mathrm{t}$ ), $30-60 \mathrm{kt} / \mathrm{yr}$ of cereals and vegetables and $4-5 \mathrm{kt} / \mathrm{yr}$ of livestock-derived products. The ecosystems were also able to deliver the amount of timber, reed and reed mace required by the local population for heating and cooking, construction and as manufacturing materials.

Preliminary results derived from the analysis of historical data, according to the conceptual model (Fig. 3) and the analytical framework shown in Fig. 4, leads to the following characterization of the reference configuration of the Inland Danube Delta-Socio Ecological System: (i) a high degree of complimentarity between local socioeconomic metabolism and major ecosystem and landscape functions, e.g. over $50 \%$ of the region's total supply with resources and services was delivered by the local natural capital, and less than $10 \%$ of the total amount of exergy (high quality energy content of the biomass which reflects the useful work that can be performed) accumulated by primary producers (NPP) was directly or indirectly diverted towards humans (Vadineanu et. al., unpublished data) and (ii) a strong resilience against local and catchment-wide socioeconomic drivers and pressures and the hydrological pulse of the Danube river. The structural configuration of the inland delta in the 1950s also enabled the LDRWS to deliver significant regulatory services. The flood detention capacity equivalent of the Inland Danube Delta was estimated at 5$9 \mathrm{~km}^{3}$, the nitrogen retention and release capacity $25 \mathrm{kt} / \mathrm{yr}$, and the phosphorous retention capacity approximately 1.6 kt/yr (Vadineanu et al., 1998, 2003; Vadineanu and Postolache, 1998).

After World War II, national policy focused on changing the formerly private ownership of land and built capital into state and "collective" ownership (1947/1959) and on chan- ging the former rural and agriculture-based economy and society into an industrialized or technology-based economy and urban society. This policy also heavily affected local and sub-regional policies. A major result was the emergence of strong pressures on ecosystems that led to massive changes in natural capital until the late 1980s. The local population size almost doubled and reached a level of 820,000 inhabitants in 1989. Urban population increased strongly and was mostly employed in secondary (54\%) and tertiary economic sectors (17\%). The local economy changed due to massive industrialization, including heavy industry, e.g. ferrous metallurgy with a capacity of 8 million tons per year (Mt/ yr), large-scale pulp and paper production, plastic production, construction of large maritime ships, hydraulic machines, furniture, textiles and food products as well as intensive agriculture (crop and meat production). These transformations were accompanied by a massive development of urban and industrial infrastructures and resulted in large yearly waste flows.

The effects of these changes on the local level, as well as downstream in the coastal Danube Delta and Black Sea ecosystems, were amplified by long distance effects of drivers and pressures from higher hierarchical levels (Fig. 4). Some of these pressures are well-documented (e.g., ecosystem conversion, emissions), while others are in an early stage of investigation. Main structural and functional changes in the Inland Danube Delta as well as elsewhere in the LDRWS have been analysed after 1990. It was found that $50 \%$ of the area of the formerly diverse natural ecosystems of the LDRWS and $80 \%$ of the area of the Inland Danube Delta were converted into agricultural land (Vadineanu and Cristofor, 1994, 2001; Vadineanu and Postolache, 1998; Vadineanu, 2007). These changes in their structural configuration brought the systems into a new functional regime that is vulnerable to the intensification of human pressures and to extreme weather events (e.g. floods, droughts). Our most recent estimations suggest that around $70 \%$ of the region's total NPP was directly used by humans as intensively cultivated crops and livestock (Vadineanu, unpublished data). Fish catches fell below $1 \mathrm{kt} / \mathrm{yr}$. The nutrient retention capacity fell below $5 \mathrm{kt} \mathrm{N} / \mathrm{yr}$ and $0.25 \mathrm{kt}$ $\mathrm{P} / \mathrm{yr}$. The flood detention capacity is now estimated to be around $1.8 \mathrm{~km}^{3}$ of water. The support function for biological diversity has also dramatically diminished due to habitat fragmentation and destruction, food availability and eutrophication (Vadineanu et al., 2001; Vadineanu, 2007; BacalbasaDobrovici and Patriche, 1999).

The current data and knowledge base provides the basic information for policy and management targets such as biodiversity conservation, ecological restoration and Local Agenda 21. The local Agenda 21 includes specific strategies and programmes, elaborated by the local authorities in cooperation with all stakeholders. These programmes aim to address the full list of critical problems and solutions concerning the relationships between environment and development at the local scale (e.g. municipality, county, region) and to promote sustainable development (United Nations Conference on Environment and Development, 1993). However, the data quality is different with respect to biodiversity, natural, socioeconomic structure and metabolism and the related drivers and pressures. 
4. Case study 2 - Doñana, Spain

Protected in 1968, the Doñana National Park $\left(537 \mathrm{~km}^{2}\right)$ is a UNESCO Biosphere Reserve, a Ramsar Site and a Natural World Heritage Site. It contains the largest wetland in Western Europe (García-Novo and Marín Cabrera, 2005), an intricate matrix of marshlands (270 $\left.\mathrm{km}^{2}\right)$, phreatic lagoons, a $25 \mathrm{~km}$ long dune ecosystem with its respective shoreline and representative Mediterranean terrestrial plant communities (Fig. 2 and Figure S2, supporting online material). Conservation objectives include the preservation of (i) critically endangered species (e.g., the Iberian Lynx, the Spanish Imperial Eagle and the Marbled Teal), (ii) of the abundance of waterfowl, and (iii) of Mediterranean wetlands and terrestrial ecosystems. Doñana is both a critical stopover site for Palearctic birds migrating to Africa and an important overwintering site for waterfowl. Inside the protected land, the main three ecosystems sustain more than 1550 species of vascular plants, 900 arthropod species, up to 400 breeding and migratory bird species, 38 mammal species, 72 species of fishes and 40 reptile and amphibian species. The Doñana marshes have a typical Mediterranean climate. The hydrological cycle starts in September and usually reaches the maximum inundation levels during the end of boreal winter, mainly driven by the rainfall regime. In late spring, evaporation becomes the most important factor in the water balance and the marshes dry up slowly to complete emptiness by the end of July. At this time, aquifer plays an important role to maintain humidity (Grimalt et al., 1999). As for most continental wetlands, inter-annual variability is basically driven by meteorology.

The Doñana LTSER platform comprises both the protected area and the surrounding territories $\left(2736 \mathrm{~km}^{2}\right)$, where a complex landscape matrix composed by rice fields, fisheries, irrigated crops, berry greenhouses, vineyards, olives and pine afforestations hold the tributary streams that pour their water to the fluvial marshland, the main figure of the Doñana. The surroundings of the Doñana hold over 180,000 permanent inhabitants. More than $60 \%$ of the employment is in agriculture and another $25 \%$ in service sectors (mainly tourism). Since the preservation of Doñana was initiated by Dr. J. A. Valverde in 1964 (when the Doñana Biological Reserve was acquired by CSIC), socioeconomic drivers have continuously counteracted preservation efforts. Even today, many underlying socioeconomic pressures are still critical to the success of conservation. The need to clearly understand the main links between socioeconomic drivers and impacts on biodiversity for every ecosystem at this LTSER platform is thus urgently felt by conservationists.

Fig. 5 shows main socioeconomic drivers and pressures in the Doñana LTSER platform and their impacts on biodiversity (EEA, 2005, 2007). There is a global agreement on the need to include socioeconomic indicators in conservation planning, a goal that is currently pursued through the implementation of a conceptual model (Martín-López et al., 2007). So far, local socioeconomic drivers and pressures have been addressed by different stakeholders and policies (responses) that are implemented with the goal of managing biodiversity and maintaining resilience. However, much less is known about links with other drivers at different scales or levels that should be identified for the Doñana LTSER platform. The marshes in the Doñana have undergone strong human-induced changes throughout the last century as a consequence of desiccation for agricultural land, redrawing of stream channels as well as biodiversity conservation and protection measures against the recent mineral waste spill (Pain et al., 1998). Overall, the marshlands that covered approximately $1,500 \mathrm{~km}^{2}$ at the beginning of the 20th century (Casado and Montes, 1991) shrunk to their current area of $270 \mathrm{~km}^{2}$, i.e. a $82 \%$ loss in area. In addition, tidal influence, one of the main inundation drivers prior to human intervention, was also limited by the construction of a wall along the margin of the Guadalquivir River (Figure S2).

\begin{tabular}{|c|c|c|c|c|c|c|c|c|c|}
\hline & \multicolumn{8}{|c|}{ Pressures } \\
\hline & & $\begin{array}{c}\text { Fragmentation } \\
\text { /Connectivity }\end{array}$ & $\begin{array}{c}\text { Modified } \\
\text { runoff regime }\end{array}$ & $\begin{array}{c}\text { Erosion / } \\
\text { Sedimentation }\end{array}$ & $\begin{array}{c}\text { Aquifer } \\
\text { overexploitation }\end{array}$ & $\begin{array}{c}\text { Water } \\
\text { Eutrophication }\end{array}$ & Water Pollution & Roads & Alien ssp / pathogens \\
\hline \multirow{7}{*}{ 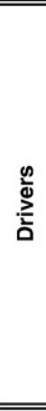 } & $\begin{array}{l}\text { Traditional } \\
\text { farming }\end{array}$ & & $\mathrm{x}$ & - & & + & ++ & $\mathrm{x}$ & \\
\hline & $\begin{array}{c}\text { Intensive } \\
\text { farming }\end{array}$ & $x$ & $x$ & + & $x$ & ++ & ++ & $x$ & $x$ \\
\hline & $\begin{array}{l}\text { Ecologic } \\
\text { farming }\end{array}$ & $\mathrm{x}$ & $\mathrm{x}$ & + & $x$ & - & - & $x$ & \\
\hline & Householding & $x$ & & & $x$ & ++ & & $x$ & \\
\hline & $\begin{array}{l}\text { Tourism } \\
\text { Facilities } \\
\end{array}$ & $x$ & & & $x$ & ++ & & $x$ & \\
\hline & $\begin{array}{c}\text { Fluvial } \\
\text { Shipping }\end{array}$ & & & $\mathrm{x}$ & & & & & $x$ \\
\hline & $\begin{array}{l}\text { Industries / } \\
\text { Mines }\end{array}$ & $\mathrm{x}$ & & $x$ & & & $x$ & $x$ & \\
\hline & & $\begin{array}{l}\text { Loss of ssp } \\
\text { population } \\
\text { viability }\end{array}$ & $\begin{array}{c}\text { Effects on } \\
\text { waterfowl } \\
\text { breeding }\end{array}$ & $\begin{array}{l}\text { Habitat loss } \\
\text { and change }\end{array}$ & $\begin{array}{c}\text { Loss of } \\
\text { Wetlands and } \\
B D\end{array}$ & $\begin{array}{c}\text { Toxical algal } \\
\text { blooms / Birds } \\
\text { outbreak }\end{array}$ & \begin{tabular}{|c} 
BD loss / mortality \\
events / drop of \\
breeding success
\end{tabular} & $\begin{array}{c}\text { Population isolation / } \\
\text { Increased mortality of } \\
\text { threatened ssp }\end{array}$ & $\begin{array}{l}\text { Competence with } \\
\text { native ssp / Trophic } \\
\text { readjustments / } \\
\text { Mortality of key-ssp }\end{array}$ \\
\hline
\end{tabular}

Fig. 5 - Most relevant drivers, pressures and impacts present in Doñana LTSER platform according to the DPSIR framework. Marked cells indicate known interaction among driver and pressure leading to an impact on biodiversity. Labels inside the cells indicate available data on strongly positive (++), positive $(+)$ or negative $(-)$ links, while cross cells (X) reveal data gaps. 
Another dramatic change was a major toxic spill in April 1998. This toxic waste spill triggered the development of an ambitious restoration project called 'Doñana 2005' with a budget of some 140 million Euro. Its main goal is to recover the quantity and quality of tributary waters entering the wetland following adaptive restoration (Lee, 1993; Holling and Allen, 2002). This effort, initiated and implemented by various administrative stakeholders, is intended to recover ecosystem services provided by the Doñana marshlands as a response to the biodiversity loss of the last decades (Chans and DíazDelgado, 2005). One of the various proposed restoration actions seeks to return the secular tidal influence to the marshlands by removing the artificial wall along the right bank of the Guadalquivir river. This decision was taken despite potential risks of new contamination episodes or spreading of invasive species (e.g. Spartina densiflora so far confined to the Guadalquivir margin; Nieva et al., 2003; Castillo et al., 2000).

For surface waters, the most important knowledge gap is the lack of information on historical inundation patterns, both spatially and temporally, and their relationships with natural variability or anthropogenic modifications. Details of the inundation processes, such as inter-annual and seasonal variation, as well as the influence of human interventions, have been demanded by decision-makers in order to develop a scientifically-based management for the Doñana marshes. So far, hydrological management has been conducted on an "event-reaction" basis, leading to temporary solutions that later often triggered new problems. Understanding how marshland is influenced by human transformations, while responding to the annual variability of rainfall, is crucial to foresee trends by using as indicators annual inundation and hydro-period, i.e. the number of days during which an area is flooded within the flooding cycle (from 1st September to 31st August). Marshland biodiversity will benefit from measures taken based on improved data on the pattern and length of inundation times, because flooding strongly influences plant communities, and the availability of flooded-area fringes increases breeding success of threatened waterfowl species.

The Common Agricultural Policy (CAP) of the European Union has also become a powerful driver of landscape dynamics since Spain was confronted with the first CAP pillar that was devoted to increasing production and productivity. Later, between 1992 and 1999, agro-environmental measures aimed to promote rural development and the integration of environmental concerns. Recent appraisals of the interrelations between CAP and biodiversity in Alter-Net project have revealed critical points in the Doñana (Díaz-Delgado \& Baudry, unpublished data): Traditional farming is being progressively abandoned and greenhouse farming and rice paddies have become the most productive crops, often subsidised by CAP payments as ecological farming, even though high yields are reached through uncontrolled groundwater pumping. Growing land demand for intensive farming has also led to increased landscape fragmentation, connectivity loss and changes in stream networks that are modifying erosion/ sedimentation regimes (García-Novo et al., 2007).

Shipping on the Guadalquivir River has also been a major pressure for the estuarine ecosystems linked to the dynamics of the Doñana marshlands. Major impacts from shipping include the increased risk of the introduction of alien species and erosion effects on the banks of the Guadalquivir River. Today, the River faces a new challenge by an ambitious project to deepen the bottom lane in order to increase the number and size of ships that can reach Sevilla harbour. Such projects clearly need scientific appraisal. Groundwater sources from the main aquifer are also critical as they provide freshwater for the irrigation of rice fields, greenhouse crops and tourism facilities. Uncontrolled increases of withdrawals have resulted in unpredictable behaviour of aquifer dynamics (Suso and Llamas, 1993). Therefore, many of the phreatic wetlands in the area have vanished or reduced their hydroperiod as a consequence of the main drop of water table due to pumping, mainly for irrigations (Custodio, 2002). Gross estimates assign to rice fields an illegal groundwater use of about 12 million $\mathrm{m}^{3}$ per year i.e. $17 \%$ of total abstractions. The annual recharge amounts to 250 million $\mathrm{m}^{3}$.

At present, first attempts to quantify main ecosystem services provided by Doñana LTSER platform are being carried out, but single economic valuation remains insufficient to reveal socioeconomic benefits from biodiversity unless cultural habits and social perception is taken into consideration (Martín-López et al., 2007). Seaside mass tourism started by the end of the 1960s, and the tourist population may surpass 200,000 visitors per summer season. Groundwater pumping for urban water supply (strongly affected by tourism) amounts to approximately 3.2 million $\mathrm{m}^{3}$ per year. Records of water tables show that characteristic temporary dune ponds inside the Park are already being affected by this abstraction regime. In essence, the Doñana LTSER platform offers a high biodiversity that is of immense attraction and benefit to several socioeconomic activities in the region that are, however, causing significant ecological pressures that in turn threaten this biodiversity.

\section{Case study 3 - Eisenwurzen, Austria}

The Eisenwurzen is a region with a long history but fuzzy boundaries (Mejzlik, 1935), defined rather by the cultural identification of the local population than by natural characteristics (Heintel and Weixlbaumer, 1998, 1999; Roth, 1998). It lies in the borderland of the federal provinces of Upper Austria, Lower Austria and Styria, and the LTSER platform Eisenwurzen is currently being developed there. The delineation of the LTSER platform is based on socioeconomic and scientific criteria as well as criteria of cultural identification according to which 99 municipalities (Fig. 2 and Figure S3, supporting online material) with its boundaries were defined, resulting in a total area of approximately $5740 \mathrm{~km}^{2}$. About $80 \%$ of the LTSER platform belongs to the eastern part of the Northern Alps, $11 \%$ to the adjacent Northern Alpine Foothills and the remaining $9 \%$ in the south to the Central Alps. Altitudes range from 210 to 2,496 m ASL with an average of $842 \mathrm{~m}$ ASL. The climate is continental with an annual precipitation ranging from $950 \mathrm{~mm}$ to $1570 \mathrm{~mm}$ and annual mean temperatures between 7.6 and $8.8{ }^{\circ} \mathrm{C}$. Temperature decreases and precipitation increases with altitude, i.e. from north to south, and it is warmer and less humid in the east 
than in the west. The geology is dominated by limestone and flysch. The Eisenwurzen region includes large woodlands covering $64 \%$ of the area, particularly in higher regions, predominantly coniferous and mixed forests. Agricultural areas - meadows and pastures (13\%) as well as arable land (6\%) - are mostly situated in the valleys. A range of seminatural and natural habitats of high nature value covers $11 \%$ of the area, including heath land, rocky outcrops or water bodies (data source: CORINE LandCover 2000). The LTSER platform Eisenwurzen has about 305,000 inhabitants, i.e. population density (53 cap $/ \mathrm{km}^{2}$ ) is lower than the Austrian average.

In the 12th century, iron ore mining set off, reaching its peak in the 16th century, when the region contributed $15 \%$ to the European iron production (Sandgruber, 1998). During the centuries, the whole region was characterised by a complex interaction of mining, metallurgy and agriculture supplying the hinterland. This involved the need for large amounts of timber for metallurgy (char burning) as well as building riverrafts for iron transport (Heintel and Weixlbaumer, 1998). Food supply for the large number of industrial workers and energy supply for industries was a major challenge for agriculture and forestry and a main driver of environmental changes. At the turn between the 17th to the 18th century, food was mainly imported into the area. High energy demand resulted in widespread deforestation. As rivers were used for transport and hydropower use, production sites were mainly located in the valleys. The forests surrounding these areas were used as a source of energy and material. Infrastructure in terms of roads for industrial activities and trade were provided by the state. Around 1930, a high demand for roads due to the increase of automobiles and public transport on the roads arose. Relocation of the roads with larger curve radius again altered the landscape (Kreuzer, 1998).

In the 1850s, the decline of the industry in the Eisenwurzen set off due to a Europe-wide economic crisis, technical improvements within the English metallurgy, and the difficulties in restructuring the production from decentralised small-scale business to mass production. This resulted in unemployment, pauperisation and depopulation of large parts of the Eisenwurzen (Sandgruber, 1998). The need for timber also declined and woodlands began to recover, in particular at higher altitudes. Afforestation and shrub encroachment are the first steps of landscape change. Studies from the area show the process of land abandonment and the different responses of vegetation to invasion and shrub encroachment (Dullinger et al., 2004; Dirnböck and Dullinger, 2004). The National Parks within the Eisenwurzen region are even facing challenges due to land abandonment. Within the agricultural sector, two opposing trends can be observed: Marginal areas experience rapid afforestation and land abandonment, whereas land-use intensity increases in flat areas, partly driven by increased crop demand due to the promotion of biofuels.

Today, tourism, agriculture and forestry are the region's main economic bases. Tourism in the alpine region is highly dependent on the region's accessibility. After 1948, the number of tourists increased due to the construction of roads, train connections, hiking paths and ski lifts (Dutzler, 1998), thus putting new pressures on the biodiversity in the Eisenwurzen. Beyond the local socioeconomic drivers, the region is also affected by external drivers (Fig. 6). Changes in socioeconomic conditions largely external to the region, such as national and supranational regional and agricultural policies, alteration of subsidy schemes, changes in prices of energy or agricultural products and many other socioeconomic trajectories (e.g., migration, economic growth, development of tourism, bio-energy policies) affect the Eisenwurzen's socio-ecological systems. A recent project has analysed the region's strengths and weaknesses with respect to sustainability (Hasenauer et al., 2007). An ongoing

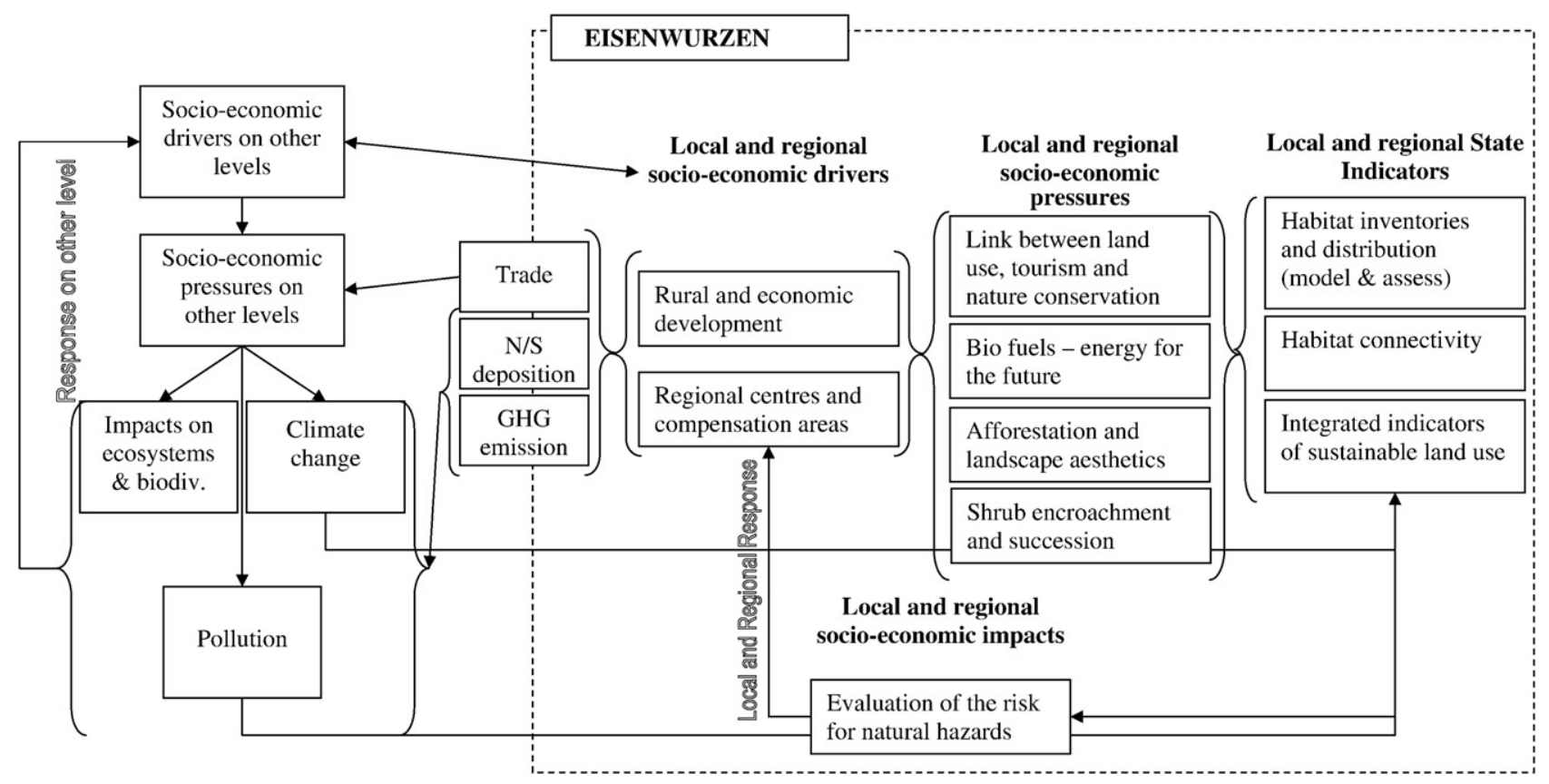

Fig. 6-Social and economic drivers and pressures on biodiversity and ecosystems in the Eisenwurzen socioecological system (LTSER platform). 
transdisciplinary project is currently using the databases made available through the LTSER platform to construct an integrated model of one of the Eisenwurzen's municipalities, Reichraming (Figure S4, online). This model can simulate socio-ecological trajectories resulting from decisions of actors, land-use change and socioeconomic and ecological material and energy flows dependent on changes in external social, political and economic conditions (e.g. CAP subsidies). This integrated model could be extended to include major ecological components relevant to biodiversity, such as landscape structure or indicators such as HANPP (see next section).

The dependence of the Eisenwurzen on forestry, agriculture and tourism as main sources of income makes it vulnerable to climate change. Species adapted to living in high mountain areas are at risk of losing their ecological niches and going extinct, with negative effects on native species richness (Grabherr et al., 1994; Pauli et al., 2003). In combination with other pressures, this could affect the composition of habitats and ecosystems and therefore also the character of the landscape. Climate change increases the risk of disastrous weather phenomena, as mountain areas are vulnerable to periods of persistent heavy rainfall or snowfall that result in the flooding of settlements and agricultural land in the valleys and endangerment by mudflows and avalanches. Nitrogen and sulphur emissions increased dramatically during the second half of the 20th century and caused excess deposition of $\mathrm{N}$ and $\mathrm{S}$ in natural and semi-natural ecosystems. Excess $\mathrm{N}$ deposition causes soil eutrophication and the increase of $\mathrm{S}$ deposition results in a significant, but soil-specific, recovery from acidification. Detected trends of soil properties were not unambiguously reflected in changes of forest floor vegetation (Dirnböck et al., 2007).

Acknowledging occurring changes of the natural environment stemming from centuries of intensive mining and industrialised manufacturing, and more recently, tourism and intensive farming, supports the assumption of the conceptual model (Fig. 3). In order to gain more insight into drivers, pressure and their effects, researchers and regional developers involved in the LTSER platform have developed a catalogue of structured questions that relate to the region and its ecological and socioeconomic conditions (see Table S2, supplementary online material and Fig. 6). The research fields addressed can be clearly structured into socioeconomic drivers and pressures as well as the state and impact following the DPSIR approach.

\section{HANPP and biodiversity in the Eisenwurzen}

One assumption behind the conceptual model presented above is that socioeconomic material and energy flows are relevant for biodiversity, thus suggesting that the analysis of the interrelations between biophysical flows and socioeconomic factors is a promising research strategy to improve our understanding of socioeconomic biodiversity pressures and drivers. Biomass use is a prominent component of socioeconomic metabolism (Weisz et al., 2006), and its extraction implies the use of land for agriculture and forestry, its relation to biodiversity is particularly plausible.

Land use induces considerable changes in patterns and processes in ecosystems, among others in the flow of trophic (nutritional) energy. The human appropriation of net primary production (HANPP) is an indicator of the intensity with which human activities affect trophic energy flows in ecosystems (Haberl et al., 2001, 2007a). Net primary production (NPP) is the net amount of primary production after the costs of plant respiration (the energy needed for the plant's metabolism) are included; it equals the amount of biomass produced per year. HANPP is the fraction of NPP appropriated by humans and has been used to assess the human domination of Earth's ecosystems (Vitousek et al., 1997). We define HANPP as the changes in the availability of NPP in ecosystems resulting from (i) alterations of the productivity of vegetation resulting from land use and (ii) extraction of NPP from ecosystems through biomass harvest (Haberl, 1997). HANPP is the difference between $\mathrm{NPP}_{0}$, the NPP of potential vegetation (Tüxen, 1956), and $\mathrm{NPP}_{t}$, the part of the NPP of actual vegetation $\left(\mathrm{NPP}_{\mathrm{act}}\right)$ remaining in ecosystems after harvest $\left(\mathrm{NPP}_{\mathrm{h}}\right)$.

Ecological theory, in particular the species-energy hypothesis discussed below, suggests that HANPP should be relevant for biodiversity. Biomass is the mass of living or dead organisms present in a system. The concept of trophicdynamic processes in ecosystems (Lindeman, 1942) is an abstract notion for organisms coming into being, growing, and dying. This process is fuelled by various metabolic processes taking place within and between organisms. Energy enters organisms above all through two processes: photosynthesis and ingestion of dead or living organisms or parts thereof. Human-induced changes in this process affect patterns (including biodiversity), processes, functions, and services of ecosystems almost by definition. But how exactly are biodiversity, resilience, or other properties of ecosystems related to HANPP? Attempts to tackle this question were based on the so-called species-energy hypothesis that postulates a negative effect of HANPP on species richness (Wright, 1990). The species-energy hypothesis (Hutchinson, 1959; Connell and Orias, 1964; Wright, 1983) suggests that more available energy should allow more species to coexist, resulting in a positive relation between energy availability and species diversity. It implies that the number of heterotrophic species present in an ecosystem is related to the amount of energy remaining in the system, i.e., $\mathrm{NPP}_{t}$, because this is the amount of energy potentially available for all food chains. According to the species-energy hypothesis HANPP contributes to species loss because it reduces $\mathrm{NPP}_{t}$ (Wright, 1990).

Direct tests of the hypothesis that HANPP reduces species richness have so far not been possible: A reduction in $\mathrm{NPP}_{\mathbf{t}}$ should result in a decline of species numbers. To test HANPP as a pressure indicator for biodiversity loss, it would be necessary to test the ability of HANPP to predict species loss $(\Delta \mathrm{S})$. In this case, this is not possible because no spatially explicit data on species loss for the region are available. Indirect tests performed so far (Haberl et al., 2004b, 2005) assume that if the current pattern of species richness $\left(\mathrm{S}_{\mathrm{act}}\right)$ is correlated to $\mathrm{NPP}_{\mathrm{t}}$, this can be taken as evidence that a reduction in $\mathrm{NPP}_{\mathbf{t}}$ should also lower species richness (Haberl et al., 2007b).

In order to perform such a test for the Eisenwurzen, we subdivided the study region by a raster with a cell size of $1 \times 1 \mathrm{~km}$, resulting in a sample of $\mathrm{N}=5695$ cells. For each cell, the mean $\mathrm{NPP}_{\mathbf{t}}$ was calculated, together with other HANPP-related indicators (Haberl et al., 2005). Data on the species richness of 


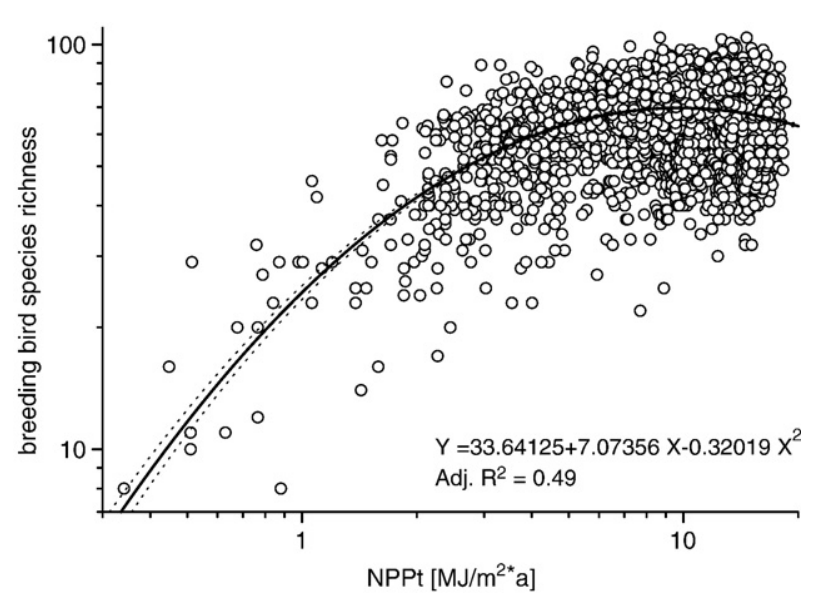

Fig. 7 -Results of the regression analyses between breeding bird species richness and NPPt in the Eisenwurzen in a $1 \times 1 \mathrm{~km}$ grid. $\mathrm{NPP}_{\mathbf{t}} \ldots$ Net primary production remaining in the ecosystem after harvest (i.e. trophic energy available each year to all heterotrophic species), BD ... species richness of breeding birds. The regression is significant at a level of pb0.01, $r^{2}=0.49$. Data sources: see text.

breeding birds on the same GIS grid were obtained from a previous study (Haberl et al., 2005). We performed regression analyses to test the relation between NPP variables and breeding bird species richness. We used linear models as well as quadratic models and afterwards the Akaike Information Criterion (AIC; Sakamoto et al., 1986) to decide which model performed better. Fig. 7 shows that we found a highly significant correlation $\left(r^{2}=0.49\right.$, significant at $\left.\mathrm{pb} 0.01\right)$ for a quadratic function between bird species richness and $\mathrm{NPP}_{\mathrm{t}}$, thus supporting results from previous studies that have also indicated strong correlations between $\mathrm{NPP}_{t}$ and biodiversity. The AIC test favoured a quadratic model that predicts a monotonous relation between $\mathrm{NPP}_{\mathrm{t}}$ and species richness for most of the $\mathrm{NPP}_{\mathrm{t}}$ interval covered by the data. HANPP is an indicator of land-use intensity within the boundary of a study region. It may be extended by calculating the HANPP "embodied" in imports and exports of biomass and biomass-derived products of a region, thus also helping to better understand the impacts of a particular region on biodiversity beyond a region's boundaries. The dependence of HANPP on socioeconomic activities, in particular on socioeconomic metabolism, as well as on geomorphological as well as climatic conditions can be analyzed based on available data (e.g., Wrbka et al., 2004). It is therefore possible to reconstruct

past trajectories of HANPP (Krausmann, 2001). The development of models that would allow the computation of future scenarios of HANPP depending on assumptions on socioeconomic and ecological trajectories seems feasible. HANPP could thus become an important element of assessments and models linking socioeconomic drivers and pressures with biodiversity.

\section{7.}

Discussion and conclusions

The three LTSER platforms used as case studies in this article differ considerably in terms of geography, climate, dominant tions and political situation. Despite these manifold differences, the conceptual model (Fig. 3) has been useful in structuring data and research efforts to better understand biodiversity pressures and drivers. The above-presented considerations also suggest that socioeconomic and ecological material and energy flows may be highly relevant for biodiversity. In particular, biomass flows through socioecological systems seem to be strongly related to patterns in biodiversity (Section 6). We are aware, nevertheless, that further research to corroborate the HANPP-biodiversity relationship would be desirable and that this relationship might be different under other environmental conditions or in other ecosystems.

The case studies also suggest that other major socioeconomic resource flows, such as metals, fossil fuels, are also highly important, either directly through the construction of infrastructures influencing ecosystems at the local scale, or indirectly through their capability to act as drivers of global environmental changes such as climate change. Research aiming at an improved understanding of the interrelations between social drivers such as demographic or institutional changes as well as changes in values, perceptions or preferences, economic drivers such as economic growth or decline, changes in dominant sectors or infrastructures and the related patterns in resource use (material, energy, land) that then, in turn, put pressures on ecosystems and biodiversity will be crucial for progress in the desired direction.

As comprehensive data to support such research are still missing in all three LTSER platforms, we conclude that major efforts would be needed to construct the required databases

Table 2 -Identifying data availability and gaps for the three case studies (No star: no data available, ${ }^{*}$ weak data availability, ${ }^{* *}$ medium data availability, ${ }^{* * *}$ good data availability)

$\begin{array}{cc}\text { Data categories } & \begin{array}{c}\text { Danube Donana Eisenwurzen } \\ \text { delta }\end{array}\end{array}$

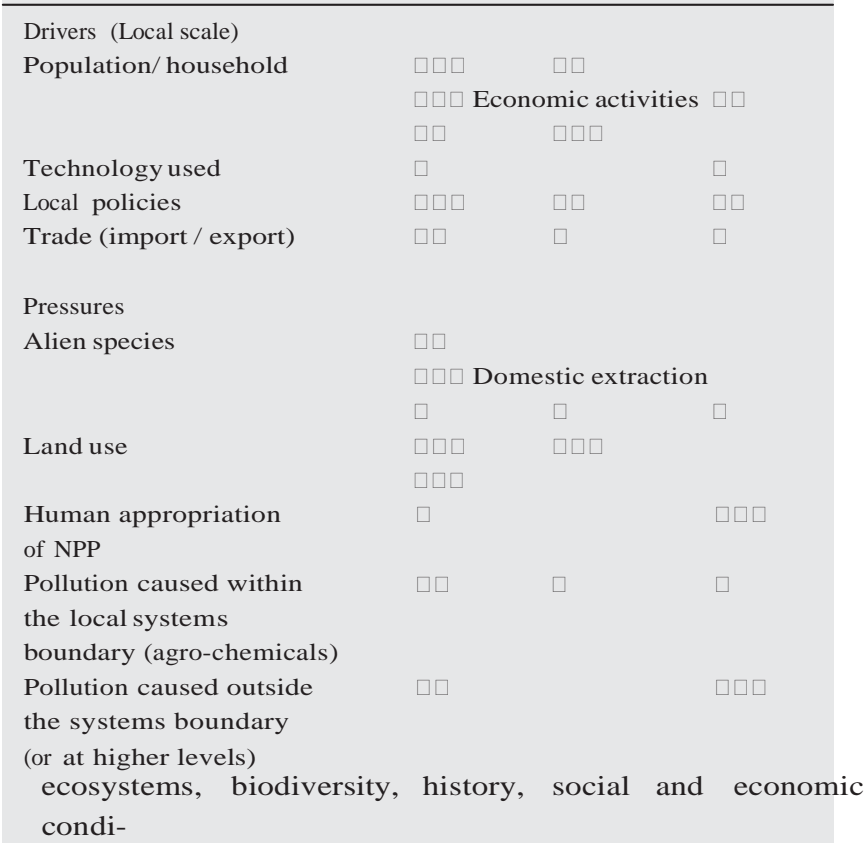


GHG emissions

States

Ecosystem

Biodiversity

$\square \square$

$\square \square$

Responses

ㅁㄷ

$\square \square \square$

$\square \square$

$\square$

$\square \square$

$\square$ 
(Table 2). Constructing and maintaining monitoring schemes and other research infrastructures to consistently gather and store data on the large range of relevant parameters - from climate to biotic communities, from economic to demographic, political or social data, from socioeconomic metabolism to biogeochemical cycles and flows - not only over a few years but over decades, and to reconstruct past states of these systems over the last decades or even hundreds of years, presents a formidable challenge involving legal, organizational and, above all, financial aspects. Only the future can tell whether proposals to install the LTSER platforms required for that will be successful.

Another important challenge are the mismatches between the scale(s) on which biodiversity is monitored and analyzed, the scale(s) on which biodiversity is managed, and the scale(s) on which conservation policies are implemented (Dirnböck et al., 2008). An in-depth discussion is beyond the scope of this paper, but the case studies underline the importance of this challenge. For example, inflows of pollutants are major biodiversity drivers in both the Danube Delta Wetland System and the Doñana. Impacts of climate change, also external to the system, have been identified as a major challenge in the mountainous Eisenwurzen LTSER platform. Influences from external socioeconomic trajectories, such as political, economic or social change at national or even international levels, are highly relevant in all three cases. Even within an area as large as the three case studies, bridging the gaps between the scales on which data from field measurements, monitoring facilities such as LTER sites, and socioeconomic and political data sources are assessed may result in considerable challenges (Dirnböck et al., 2008; Haberl et al., 2006b).

The need for inter- and transdisciplinary research (i.e. across scientific disciplines and with stakeholder involvement), is also crucial. All three cases suggest that conceptual models such as that presented in Fig. 3 are decisive as a communicative framework that helps integrating different approaches in a coherent overall picture. The need for formal, i.e. computer-executable models, however, is rising as well, partly due to their capability to anticipate possible future biodiversity change under different assumptions on future socioeconomic trajectories (i.e., scenarios). Moreover, experiences in ongoing research projects discussed above (Section 5) suggest that such models can be helpful in integrating contributions from different disciplines in a consistent way, thus helping to promote the understanding of complex socioecological systems (van der Leeuw, 2004). Innovative models that combine agent-based approaches (McConnell, 2001; Manson and Evans, 2007) with stock-flow modules in a coherent model can be useful in that context. While we do not expect full-blown mathematical models covering all aspects shown in Fig. 3 to emerge in the near future, we nevertheless hope that the conceptual model discussed in this article will at least help to build simulation models of selected important parts of the interdependencies discussed here, to establish databases of available data required for such models, as well as schemes or programmes to monitor or reconstruct the development of important parameters that are at present not (sufficiently) covered. Experiences in the Eisenwurzen suggest that such models are feasible and could be highly useful in integrating stakeholders in participative research processes, thus also increasing the utility of the research for people living in the respective study regions.

We conclude that LTSER can help in supplying data and knowledge critical to better-informed policy- and decisionmaking, thus supporting sustainable development. Our analyses suggest considerable data gaps and therefore need for further research and monitoring and may thus be helpful in guiding ways forward to a more integrated scientific agenda to support biodiversity conservation and sustainability.

\section{Acknowledgements}

We acknowledge financial support by ALTER-Net, a Network of Excellence funded by the EU within its 6th Framework Programme, by the Austrian Federal Ministry of Education, Science and Culture within the project "LTSER Eisenwurzen" (proVISION). This research contributes to the Global Land Project (GLP, http://www.globallandproject.org).

\section{Appendix A. Supplementary data}

Supplementary data associated with this article can be found, in the online version, at doi:10.1016/j.ecolecon.2008.11.013.

\section{R E F E R E N C E S}

Antipa, G., 1910. Regiunea inundabila a Dunarii - Starea ei actuala si mijloacele de a o pune in valoare (Danube floodplains: current status and means of valorification). Instit. de Arte Grafice Carol Gobi, Bucuresti.

Ayres, R.U., Simonis, U.E. (Eds.), 1994. Industrial Metabolism: Restructuring for Sustainable Development. United Nations University Press, Tokyo.

Bacalbasa-Dobrovici, N., Patriche, N., 1999. Environmental studies and recovery actions for sturgeons in the Lower Danube River System. Journal of Applied Ichthyology 15, 114-115.

Biggs, R., Scholes, R.J., ten Brink, B.J.E., Vackár, D., 2007. Biodiversity indicators. In: Hak, T., Moldan, B., Dahl, A.L. (Eds.), Sustainability Indicators. A Scientific Assessment. Island Press, Washington, D.C., pp. 249-270.

Casado, S., Montes, C., 1991. Estado de conservación de los humedales peninsulares españoles. Quercus 66, 18-26.

Castillo, J.M., Fernández-Baco, L., Castellandos, E.M., Luque, C.J., Figueroa, M.E., Davy, A.J., 2000. Lower limits of Spartina densiflora and S. maritima in a Mediterranean salt marsh determined by different ecophysiological tolerances. Journal of Ecology 88, 801-812.

CBD, 2003. Consideration of the results of the meeting on " 2010 : The global biodiversity challenge”. UNEP/CBD/SBSTTA/9/inf/9, Convention on Biological Diversity, Montreal, Canada.

Chans, J.J., Díaz-Delgado, R., 2005. Monitoring and evaluation: the key to the Doñana 2005 restoration project. In: García-Novo, F., Marín Cabrera, C. (Eds.), Doñana, Water and Biosphere. Doñana 2005, CHG-MMA, Madrid, pp. 319-326.

Chapin III, F.S., Zavaleta, E.S., Eviner, V.T., Naylor, R., Vitousek, P.M., Reynolds, H.L., Hooper, D.U., Lavorel, S., Sala, O.E., Hobbie, S.E., Mack, M.C., Diaz, S., 2000. Consequences of changing biodiversity. Nature 405, 234-242. 
ChapinIII III, F.S., Sala, O.E., Huber-Sannwald, E. (Eds.), 2001. Global Biodiversity in a Changing Environment. Scenarios for the 21st Century. Springer, New York.

Clark, W.C., Dickson, N.M., 2003. Sustainability science: the emerging research program. Proceedings of the National Academy of Sciences of the United States of America 100, 8059-8061.

Cleveland, C.J., Stern, D.I., Costanza, R. (Eds.), 2001. The Economics of Nature and the Nature of Economics. Edward Elgar, Cheltenham.

Connell, J.H., Orias, E., 1964. The ecological regulation of species diversity. American Naturalist 98, 399-414.

Custodio, E., 2002. Aquifer overexploitation: what does it mean? Hydrogeology Journal 10, 254-277.

Daniels, P.L., 2002. Approaches for quantifying the metabolism of physical economies: a comparative survey. Part II - review of individual approaches. Journal of Industrial Ecology 6, 65-88.

Daniels, P.L., Moore, S., 2001. Approaches for quantifying the metabolism of physical economies, Part I: methodological overview. Journal of Industrial Ecology 5, 69-93.

Delbaere, B., 2002. Biodiversity Indicators and Monitoring: Moving Towards Implementation. European Centre for Nature Conservation (ECNC), Tilburg.

Delbaere, B., 2003. An inventory of biodiversity indicators in Europe, 2002. Technical Report No 92. European Environment Agency (EEA), Copenhagen.

Dirnböck, T., Dullinger, S., 2004. Habitat distribution models, spatial autocorrelation, functional traits and dispersal capacity of alpine plant species. Journal of Vegetation Science 15, 77-84.

Dirnböck, T., Mirtl, M., Dullinger, S., Grabner, M., Hochrathner, P., Hülber, K., Karrer, G., Kleinbauer, I., Mayer, W., Peterseil, J., Pfefferkorn-Dellali, V., Reimoser, F., Reimoser, S., Türk, R., Willner, W., Zechmeister, H., 2007. Effects of nitrogen and sulphur deposition on forests and forest biodiversity. Austrian Integrated Monitoring Zöbelboden. Federal Environment Agency, Vienna.

Dirnböck, T., Bezák, P., Dullinger, S., Haberl, H., Lotze-Campen, H., Mirtl, M., Peterseil, J., Redpath, S., Singh, S.J., Travis, J., Wijdeven, S.M.J., 2008. Scaling issues in long-term socio-ecological biodiversity research. A review of European cases. Social Ecology Working Paper No. 100. Institute of Social Ecology, Vienna.

Dullinger, S., Dirnböck, T., Grabherr, G., 2004. Modelling climate change-driven treeline shifts: relative effects of temperature increase, dispersal and invasibility. Journal of Ecology 241-252.

Dutzler, A., 1998. Alpinismus und Fremdenverkehr. In: Landeskulturdirektion Oberösterreich (Ed.), Land der Hämmer - Heimat Eisenwurzen. OÖ Landesregierung, Linz, pp. 130-135.

EEA, 2005. The European Environment - State and Outlook 2005. European Environment Agency, Copenhagen.

EEA, 2007. Europe's environment. The fourth assessment. European Environment Agency, Copenhagen.

Erb, K.-H., 2004. Actual land demand of Austria 1926-2000: a variation on ecological footprint assessments. Land Use Policy 21, 247-259.

Eurostat, 2001. Economy-wide material flow accounts and derived indicators. A methodological guide. Eurostat, European Commission, Office for Official Publications of the European Communities, Luxembourg.

Fischer-Kowalski, M., 1998. Society's metabolism. The intellectual history of material flow analysis, Part I: 1860-1970. Journal of Industrial Ecology 2, 61-78.

Fischer-Kowalski, M., Erb, K.-H., 2003. Gesellschaftlicher Stoffwechsel im Raum. Auf der Suche nach einem sozialwissenschaftlichen Zugang zur biophysischen Realität. In: Meusburger, P., Schwan, T. (Eds.), Humanökologie. Ansätze zur Überwindung der Natur-Kultur-Dichotomie. Steiner Verlag, Stuttgart, pp. 257-285.
Fischer-Kowalski, M., Hüttler, W., 1998. Society's metabolism. The intellectual history of material flow analysis, Part II: 1970-1998. Journal of Industrial Ecology 2, 107-137.

Fischer-Kowalski, M., Weisz, H., 1999. Society as hybrid between material and symbolic realms. Toward a theoretical framework of society-nature interaction. Advances in Human Ecology 8, 215-251.

García-Novo, F., Marín Cabrera, C., 2005. Doñana, water and biosphere. Doñana 2005. CHG-MMA, Madrid.

García-Novo, F., Escudero Garcia, J.C., Carotenuto, L., García Sevilla, D., Fernández Lo Faso, R.P., 2007. The restoration of El Partido stream watershed (Donana Natural Park): a multiscape, interdisciplinary approach. Ecological Engineering 30 (2), 122-130.

Grabherr, G., Gottfried, M., Pauli, H., 1994. Climate effects on mountain plants. Nature 369, 448.

Grimalt, J.O., Ferrer, M., Macpherson, E., 1999. The mine tailing accident in Aznalcollar. Science of the Total Environment 242, 3-11.

Haberl, H., 1997. Human appropriation of net primary production as an environmental indicator: implications for sustainable development. Ambio 26, 143-146.

Haberl, H., 2001a. The energetic metabolism of societies, Part I: accounting concepts. Journal of Industrial Ecology 5 (1), 11-33.

Haberl, H., 2001b. The energetic metabolism of societies, Part II: empirical examples. Journal of Industrial Ecology 5 (2), 71-88.

Haberl, H., Erb, K.-H., Krausmann, F., Loibl, W., Schulz, N.B., Weisz, H., 2001. Changes in ecosystem processes induced by land use: human appropriation of net primary production and its influence on standing crop in Austria. Global Biogeochemical Cycles 15, 929-942.

Haberl, H., Fischer-Kowalski, M., Krausmann, F., Weisz, H., Winiwarter, V., 2004a. Progress towards sustainability? What the conceptual framework of material and energy flow accounting (MEFA) can offer. Land Use Policy 21, 199-213.

Haberl, H., Schulz, N.B., Plutzar, C., Erb, K.-H., Krausmann, F., Loibl, W., Moser, D., Sauberer, N., Weisz, H., Zechmeister, H.G., Zulka, P., 2004b. Human appropriation of net primary production and species diversity in agricultural landscapes. Agriculture, Ecosystems \& Environment 102, 213-218.

Haberl, H., Plutzar, C., Erb, K.-H., Gaube, V., Pollheimer, M., Schulz, N.B., 2005. Human appropriation of net primary production as determinant of Avifauna diversity in Austria. Agriculture, Ecosystems \& Environment 110, 119-131.

Haberl, H., Weisz, H., Amann, C., Bondeau, A., Eisenmenger, N., Erb, K.-H., Fischer-Kowalski, M., Krausmann, F., 2006a. The energetic metabolism of the EU-15 and the USA. Decadal energy input time-series with an emphasis on biomass. Journal of Industrial Ecology 10 (4), 151-171.

Haberl, H., Winiwarter, V., Andersson, K., Ayres, R.U., Boone, C.G., Castillio, A., Cunfer, G., Fischer-Kowalski, M., Freudenburg, W.R., Furman, E., Kaufmann, R., Krausmann, F., Langthaler, E., Lotze-Campen, H., Mirtl, M., Redman, C.A., Reenberg, A., Wardell, A.D., Warr, B., Zechmeister, H., 2006b. From LTER to LTSER: conceptualizing the socio-economic dimension of long-term socio-ecological research. Ecology and Society 11, 13 [online], http://www.ecologyandsociety.org/vol11/iss2/art13/.

Haberl, H., Erb, K.-H., Krausmann, F., Gaube, V., Bondeau, A., Plutzar, C., Gingrich, S., Lucht, W., Fischer-Kowalski, M., 2007a. Quantifying and mapping the human appropriation of net primary production in earth's terrestrial ecosystems. Proceedings of the National Academy of Sciences 104, 12942-12947.

Haberl, H., Erb, K.-H., Plutzar, C., Fischer-Kowalski, M., Krausmann, F., 2007b. Human appropriation of net primary production (HANPP) as indicator for pressures on biodiversity. In: Hak, T., Moldan, B., Dahl, A.L. (Eds.), Sustainability 
Indicators. A Scientific Assessment. SCOPE. Island Press, Washington, D.C., pp. 271-288.

Hasenauer, H., Putzhuber, F., Mirtl, M., Wenzel, W., 2007. Multifunctional land use: the Eisenwurzen region of the Austrian Alps. In: Mander, Ü., Wiggering, H., Helming, K. (Eds.), Multifunctional Land Use. Meeting Future Demands for Landscape Goods and Services. Springer, Heidelberg, pp. 341-354.

Heintel, M. and Weixlbaumer, N., 1998. Region Eisenwurzen: Ein geographisch-kulturräumlicher Begriff. In:

Landeskulturdirektion Oberösterreich (Ed.), Land der Hämmer. Heimat Eisenwurzen. Residenz Verlag, Salzburg, pp. 16-23.

Heintel, M., Weixelbaumer, N., 1999. Oberösterreichische Eisenwurzen/Eisenstraße III: Langzeitstudie (1995-1999) zur räumlichen Abgrenzung, Akzeptanz und regionale Identität der Region Eisenwurzen bzw. der Eisnestraßenidee:

Endergebnisse. Institut für Geographie und Regionalentwicklung der Universität, Vienna.

Heywood, V.H., Watson, R.T. (Eds.), 1995. Global Biodiversity Assessment. Cambridge University Press, United Nations Environment Programme (UNEP), Cambridge.

Holling, C.S., Allen, C.R., 2002. Adaptive inference for distinguishing credible from incredible patterns in nature. Ecosystems 5, 319-328.

Hutchinson, G.E., 1959. Homage to Santa Rosalia, or why are there so many kinds of animals? The American Naturalist 93, 145-159.

Kates, R.W., Clark, W.C., Corell, R., Hall, J.M., Jaeger, C.C., Lowe, I., McCarthy, J.J., Schellnhuber, H.J., Bolin, B., Dickson, N.M., Faucheux, S., Gallopin, G.C., Grübler, A., Huntley, B., Jäger, J., Jodha, N.S., Kasperson, R.E., Mabogunje, A., Matson, P.A., Mooney, H.A., Moore III, B., O'Riordan, T., Svedin, U., 2001. Sustainability science. Science 292, 641-642.

Krausmann, F., 2001. Land use and industrial modernization: an empirical analysis of human influence on the functioning of ecosystems in Austria 1830 - 1995. Land Use Policy 18, 17-26.

Krausmann, F., Haberl, H., Erb, K.-H., Wackernagel, M., 2004. Resource flows and land use in Austria 1950-2000: using the MEFA framework to monitor society-nature interaction for sustainability. Land Use Policy 21, 215-230.

Kreuzer, B., 1998. Eine Region wird mobil. In: Landeskulturdirektion Oberösterreich (Ed.), Land der Hämmer - Heimat Eisenwurzen. OÖ Landesregierung, Linz, pp. $122-129$.

Lee, K.N., 1993. Compass and Gyroscope. Integrating Science and Politics for the Environment. Island Press, Washington, D.C.

Lindeman, R.L., 1942. The trophic-dynamic aspect of Ecology. Ecology 23, 399-417.

Magurran, A., 1988. Ecological Diversity and Its Measurement. Chapman \& Hall, London.

Manson, S.M., Evans, T., 2007. Agent-based modeling of deforestation in southern Yucatán, Mexico, and reforestation in the Midwest United States. Proceedings of the National Academy of Sciences of the United States of America 104, 20678-20683.

Martín-López, B., Montes, C., Benayas, J., 2007. The non-economic motives behind the willingness to pay for biodiversity conservation. Biological Conservation 139, 67-83.

Martinez-Alier, J., 1999. The socio-ecological embeddedness of economic activity: the emergence of a transdisciplinary field. In: Becker, E., Jahn, T. (Eds.), Sustainability and the Social Sciences. Zed Books, London, pp. 112-139.

McConnell, W., 2001. Agent-Based Models of Land-use and Land-cover Change. LUCC International Project Office, Belgium.

Mejzlik, H., 1935. Die nördlichen Eisenwurzen in Österreich. Carl Heymannsverlag und Österreichischer Wirtschaftsverlag. Wien, Berlin.

Mirtl, M., Krauze, K., 2007. Developing a new strategy for environmental research, monitoring and management: The
European Long-Term Ecological Research Network's (LTER-Europe) role and perspectives. In: Chmielewski, T. (Ed.), Nature Conservation Management: From Idea to Practical Results. ALTER-Net, Lublin, Lodz, Helsinki, Aarhus, pp. 36-52.

Nieva, F.J.J., Castillo, J.M., Luque, C.J., Figueroa, M.E., 2003. Ecophysiology of tidal and non-tidal populations of the invading cordgrass Spartina densiflora: seasonal and diurnal patterns in a Mediterranean climate. Estuarine, Coastal and Shelf Science 57, 919-928.

Ohl, C., Krauze, K., Grünbühel, C.M., 2007. Towards an understanding of long-term ecosystem dynamics by merging socio-economic and environmental research. Criteria for long-term socio-ecological research sites selection. Ecological Economics 63, 383-391.

Pain, D.J., Sánchez, A., Meharg, A.A., 1998. The Doñana ecological disaster: contamination of a word heritage estuarine marsh ecosystem with acidified pyrite mine waste. Science of the Total Environment 222, 45-54.

Pauli, H., Gottfried, M., Dirnböck, T., Dullinger, S., Grabherr, G., 2003. Assessing the long-term dynamics of endemic plants at summit habitats. In: Nagy, L., Grabherr, G., Körner, C., Thompson, D.B.A. (Eds.), Alpine Biodiversity in Europe - A Europe-wide Assessment of Biological Richness and Change. Springer, Berlin, pp. 195-207.

Roth, P.W., 1998. Die Eisenwurzen: Eine Region in drei Ländern. In: Landeskulturdirektion Oberösterreich (Ed.), Land der Hämmer - Heimat Eisenwurzen. OÖ Landesregierung, Linz, pp. 36-40.

Sakamoto, Y., Ishiguro, M., Kitagawa, G., 1986. Akaike Information

Criterion Statistics. D. Reidel Publishing Company, Tokyo. Sala, O.E., Chapin III, F.S., Armesto, J.J., Berlow, E., Bloomfield, J., Dirzo, R., Huber-Sannwald, E., Huennecke, L.F., Jackson, R.B., Kinzig, A., Leemans, R., Lodge, D.M., Mooney, H.A., Oesterheld, M., Poff, N.L., Sykes, M.T., Walker, B., Walker, M., Wall, D.H., 2000. Global biodiversity scenarios for the year 2100. Science 287, 1770-1774.

Sandgruber, R., 1998. Heimat Eisenwurzen. In: Landeskulturdirektion Oberösterreich (Ed.), Land der Hämmer - Heimat Eisenwurzen - Katalog zur gleichnamigen Landesausstellung 1998. OÖ Landesregierung, Linz, pp. 187-197.

Scholes, J.R., Biggs, R., 2005. A biodiversity intactness index. Nature 434, 45-49.

Schor, J.B., 2005. Sustainable consumption and worktime reduction. Journal of Industrial Ecology 9, 37-50.

Spangenberg, J.H., 2007. Biodiversity pressure and the driving forces behind. Ecological Economics 61, 146-158.

Suso, J., Llamas, M.R., 1993. Influence of groundwater development on the Doñana National Park ecosystems (Spain). Journal of Hydrology 141, 239-269.

Tüxen, R., 1956. Die heutige potentielle natürliche Vegetation als Gegenstand der Vegetationskartierung. Angewandte Pflanzensoziologie 13, 5-42.

United Nations Conference on Environment and Development, 1993. Agenda 21: Programme of Action for Sustainable Development. Rio Declaration on Environment and Development. Statement of Forest Principles. The final text of agreements negotiated by Governments at the United Nations Conference on Environment and Development (UNCED), 3-14 June 1992, Rio de Janeiro, Brazil. United Nations, New York.

Vadineanu, A., 2007. The ecosystem approach applied to the management of the coastal socio-ecological systems. In: Gonenc, I.E., Koutitousky, V.G., Rasleigh, B., Ambrose, R.B.J., Wolflin, J.P. (Eds.), Assessment of the Fate and Effects of Toxic Agents on Water Resources. Springer, Dordrecht, pp. 199-224.

Vadineanu, R.S., 2008. Conceptual models and operational tools for designing and management the sustainable development of socio-ecological systems: application at regional and national scales. Report of the University of Bucharest, Bucharest. 
Basic requirements for the assessment and management of large international water systems: Danube River/Black Sea. In: Vadineanu, A., Cristofor, S. (Eds.), Proceedings of the International workshop: Monitoring Tailormade. Beekbergen, The Netherlands, pp. 71-81.

Vadineanu, A., Cristofor, S., 2001. Biodiversity changes in the Lower Danube River System. In: Gopal, B., Junk, J.W., Davis, A.J. (Eds.), Biodiversity in Wetlands: Assessment, Function and Conservation. Backhuys Publ., Leiden, pp. 29-65.

Vadineanu, A., Postolache, C., 1998. Targets concerning socio-economic restructuring emerged from the material accounting analysis at the national scale. In: Hens, L., Borden, J.R., Suzuki, S., Caravello, G. (Eds.), Research in Human Ecology: An Interdisciplinary Overview. VUB Press, Bruxelles, pp. 288-314.

Vadineanu, A., Cristofor, S., Sarbu, A., Romanca, G., Ignat, G., Botnariuc, N., Ciubuc, C., 1998. Changes of biodiversity along the Lower Danube River System. International Journal of Ecology and Environmental Science 24, 315-332.

Vadineanu, A., Adamescu, M.C., Cazacu, C., Bodescu, F., Danielescu, S., 2001. Past and future management of the Lower Danube Wetlands. Working paper of the Dept. of System Ecology. Bucharest University, Bucharest.

Vadineanu, A., Adamescu, M.C., Vadineanu, R.S., Christofor, S., Negrei, C., 2003. Past and future management of the Lower Danube Wetland System: a bioeconomic appraisal. The Journal of Interdisciplinary Economics 14, 415-447.

van der Leeuw, S.E., 2004. Why Model? Cybernetics and Systems $35,117-128$.
Vitousek, P.M., Mooney, H.A., Lubchenco, J., Melillo, J.M., 1997. Human Domination of Earth`s Ecosystems. Science 277, 494-499.

Wackernagel, M., Rees, W.E., 1996. Our ecological footprint, Reducing human impact on the Earth. New Society Publishers, Gabriola Island, BC.

Weisz, H., 2006. The use of input-output economics to account for environmentally unequal trade. In: Hornborg, A., Martinez-Alier, J., McNeill, J.R. (Eds.), Rethinking Environmental History: World System History and Global Environmental Change. Rowman \& Littlefield, AltaMira, pp. 298-306.

Weisz, H., Krausmann, F., Amann, C., Eisenmenger, N., Erb, K.-H., Hubacek, K., Fischer-Kowalski, M., 2006. The physical economy of the European Union: cross-country comparison and determinants of material consumption. Ecological Economics 58, 676-698.

Wrbka, T., Erb, K.-H., Schulz, N.B., Peterseil, J., Hahn, C., Haberl, H., 2004. Linking pattern and processes in cultural landscapes. An empirical study based on spatially explicit indicators. Land Use Policy 21, 289-306.

Wright, D.H., 1983. Species-energy theory: an extension of the species-area theory. Oikos 41, 495-506.

Wright, D.H., 1990. Human impacts on the energy flow through natural ecosystems, and implications for species endangerment. Ambio 19, 189-194.

Zechmeister, H.G., Dirnböck, T., Hülber, K., Mirtl, M., 2007. Assessing airborne pollution effects on bryophytes - lessons learned through long-term integrated monitoring in Austria. Environmental Pollution 147, 696-705. 